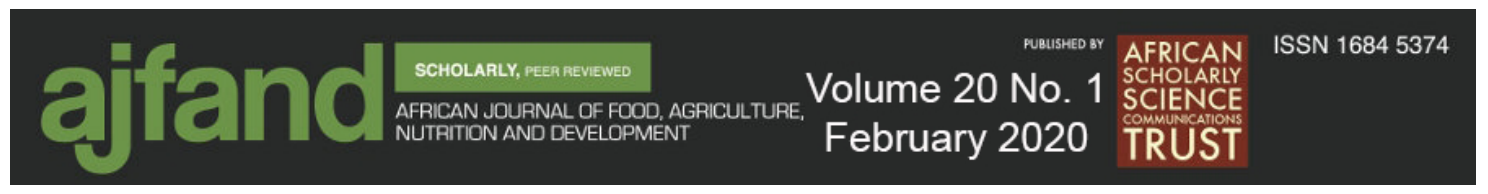

Afr. J. Food Agric. Nutr. Dev. 2020; 20(1): 15415-15430

DOI: 10.18697/ajfand.89.18900

\title{
DETERMINING GRAIN SEED MICRONUTRIENT CONTENTS (IRON AND ZINC) AND COOKING TIME FOR SELECTED DRY BEAN CULTIVARS
}

\section{Binagwa $\mathrm{PH}^{1 *}$, $\mathrm{He} \mathrm{G}^{2}$, Bonsi $\mathrm{E}^{3}$, Traore $\mathrm{SM}^{2}$, Jaynes $\mathrm{J}^{2}$ and $\mathrm{CK}$ Bonsi ${ }^{2}$}

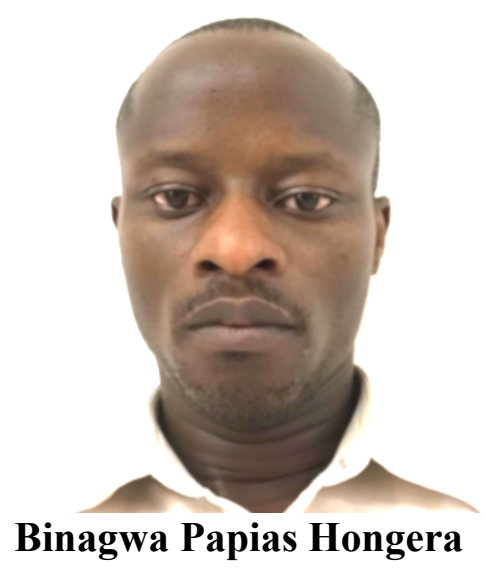

*Corresponding author email: pbinagwa8224@,tuskegee.edu

${ }^{1}$ Integrative Biosciences (IBS) Ph.D. Program, Tuskegee University, AL 36088, USA

${ }^{2}$ Department of Agricultural and Environmental Sciences, Tuskegee University, AL 36088, USA

${ }^{3}$ Department of Food and Nutritional Sciences, Tuskegee University, AL 36088, USA 


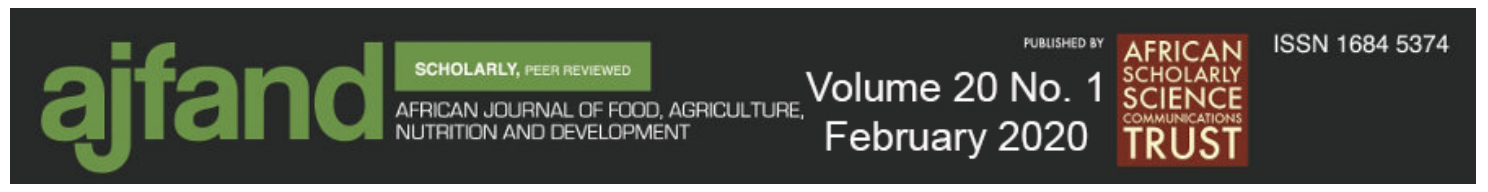

\begin{abstract}
Micronutrient deficiencies caused by lack of Iron (Fe), Zinc ( $\mathrm{Zn})$ and Vitamin A in the human body have negative effect with regard to health issues worldwide. Imbalances of these nutrients in the human body create a significant risk of illness and mortality among children under five years of age, pregnant women and lactating mothers. Some of the food crops that thought to reduce micronutrients include rice, sweet potato, dry bean, sorghum, corn, barley, and finger millet have been biofortified through ways of agronomic practices, conventional breeding, or modern biotechnology. Despite the fact that dry beans address $\mathrm{Fe}$ and $\mathrm{Zn}$ deficiencies based on recommended dietary allowances (RDA), they often take a long time to cook. Many communities have limited cooking resources which make them rely on burning wood, charcoal or other biofuels that require more time and money. This study identified dry bean cultivars with enhanced Fe and $\mathrm{Zn}$ concentration levels and fast cooking time from 200 cultivars. Experiments were conducted under a complete randomized block design with two replications, 200 cultivars, and two different agro-ecologies. Iron and Zinc concentration levels were determined from the harvested seed grains of each bean cultivar using X-Ray Fluorescence while cooking time of similar cultivars were determined using the Mattson cooker. The variation of $\mathrm{Fe}$ and $\mathrm{Zn}$ concentration was significantly different at $(\mathrm{p}<0.001)$ among the treatments and environments. The range was between $46.76 \mathrm{mg} / \mathrm{kg}$ to 107.25 $\mathrm{mg} / \mathrm{kg}$ for $\mathrm{Fe}$ and $21.70 \mathrm{mg} / \mathrm{kg}$ to $42.35 \mathrm{mg} / \mathrm{kg}$ for $\mathrm{Zn}$ concentration. From two testing sites, the concentration of Fe was higher at Lyamungo than SARI and $\mathrm{Zn}$ showed inversely proportional to these tested sites which means that the environment and soils were not homogenous in terms of soil health. The highest water uptake was $61.54 \%$ and the lowest was 3.70\% and the higher the water uptake the lower the cooking time. Fast cooking time was $\sim 15 \mathrm{~min}$ and the longest was $\sim 76 \mathrm{~min}$. Small seed-sized cultivars showed fast cooking time than large-seeded. These two traits in identified cultivars will enhance dry bean consumption, which will contribute to alleviating micronutrient deficiencies in this global growing population.
\end{abstract}

Key words: Micronutrient deficiencies, Biofortification, Cultivars, Cooking time, Vulnerable group, Variation 


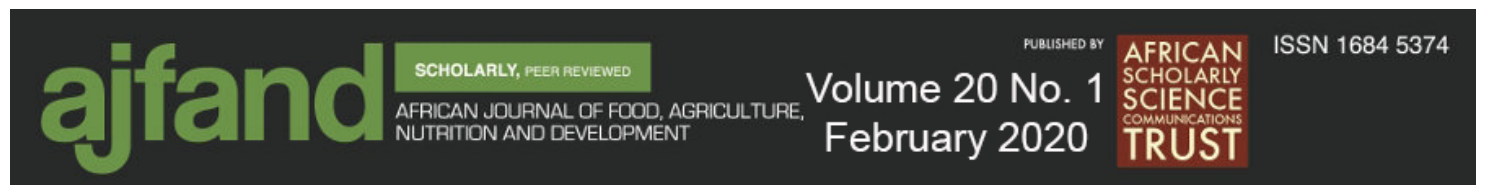

\section{INTRODUCTION}

Iron and Zinc are essential micronutrients for body growth, development, reproduction and other physiological functions in the human body [1]. The available data on zinc level in serum and seminal plasma suggests that zinc has a significant role in spermatogenesis and maintaining the total number of sperms as well as sperm motility and DNA integrity $[1,2,3]$. Also, Iron deficiency in the human body is one of the most common micronutrient deficiencies affecting women, children, and infants most severely and it is especially prevalent in resource-poor individuals [4]. Among the functional consequences of iron deficiency include decreased physical performance and physical activity, decreased cognitive performance, depression, and fatigue [5]. The nutritional strategies to reduce this burden of micronutrient deficiency in the growing global population include dietary diversity, supplementation, fortification, and biofortification of food crops $[6,7]$. This study addresses one of these strategies to enhance Fe and $\mathrm{Zn}$ in staple foods by selecting crops that have the potential to become a sustainable, inexpensive, and effective solution of addressing Fe and $\mathrm{Zn}$ deficiencies in people. One of the crops identified for biofortification is dry beans (Phaseolus vulgaris L.). This dry bean is a leguminous grain, which plays an important role in human nutrition being one of the main foods in the standard diet of low-income people in developing countries [8]. Dry bean is an important source of nutrients for more than 300 million people in parts of Eastern Africa and Latin America providing Fe, $\mathrm{Zn}$, thiamin and folic acid [9]. It represents $65 \%$ of the total protein consumed $[10,11]$. Despite the fact that dry beans are a rich source of $\mathrm{Fe}$ and $\mathrm{Zn}$, some cultivars often take a long time to cook. This causes people not to add beans to their meals. Moreover, it requires the use of either gas, charcoal or firewood depending on the type of fuel source used $[12,13]$. In developed countries, consumers do not have time to invest in cooking [14] and hence the need for fast cooking dry beans to reduce the time of staying in the kitchen. For example, in the United States of America (USA). The term convenience is highly significant because the average household spends only 60 minutes per day on meal preparation [15]. Some studies showed that the iron bioavailability is also higher in the quicker cooking beans in different tested bean market classes [16]. Fast cooking with better micronutrient bioavailability has an impact on bean consumption. Therefore, in this study, our objective was to screen the dry bean germplasm for the identification of cultivars with low cooking time and enhanced micronutrient content through genotype and environment interactions.

\section{MATERIALS AND METHODS}

Acquisition of dry bean cultivars: A collection of 200 cultivars with diverse sources and market classes was used in this study. Twelve cultivars were collected from Ethiopia, 173 from International Center for Tropical Agriculture (CIAT)- Kawanda, 10 from Kenya, 3 from Tanzania and 2 from Rwanda based on the previous season under Tropical Legume three project. These cultivars were morphologically different from market classes to seed size classifications (Fig. 1). 

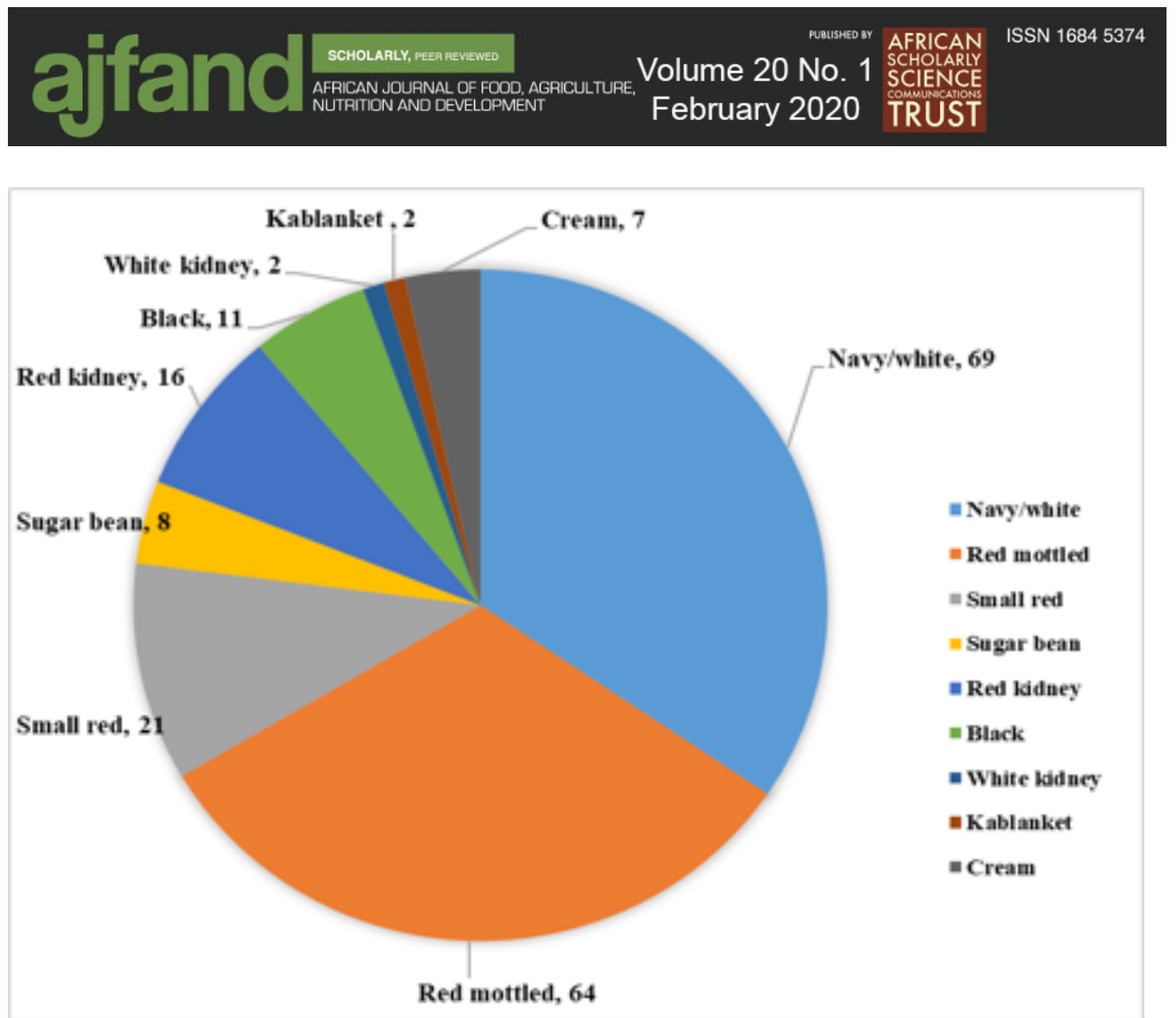

Figure 1: Dry bean market classes used in this research

Field experimental design. The experiment was conducted at low to high altitudes with $1407 \mathrm{~m}$ above sea level (a.s.l) of S03 21.690' and E36 37.879' Selian Agricultural Research Institute (SARI) and Tanzania Coffee Research Institute commonly called Lyamungo with $992 \mathrm{~m}$ a.s.1 of S03 ${ }^{\circ} 19.905^{\prime}$ and E037 $14.067^{\prime}$, respectively. The soil characteristics of these areas were Eutrophic Brown Soils on volcanic and Alluvial sediments - medium texture (loamy soils), range of Fe is $29.85 \mathrm{mg} / \mathrm{kg}$ to $39.24 \mathrm{mg} / \mathrm{kg}$ and $\mathrm{Zn}$ is $0.33 \mathrm{mg} / \mathrm{kg}$ to $0.60 \mathrm{mg} / \mathrm{kg}$ [17]. Trials were laid out in Complete Randomized Block Design (CRBD) with two replications for 200 common bean cultivars in two agroecologies. The experimental plot size was 4 rows, $3.2 \mathrm{~m}$ long and $50 \mathrm{~cm}$ apart and $20 \mathrm{~cm}$ within a row and was under rainfed.

Sampling and sample preparation for $\mathbf{F e}$ and $\mathrm{Zn}$ determination: At full maturity, 30 well-filled pods were randomly harvested from each plot of two centered rows and placed in a new clean paper envelope. Total of 100 seeds per cultivar were sampled and dried in an Oven (Binder drying chamber, Model: ED 115, Tuttlingen, Germany) for $12 \mathrm{hrs}$. at $60^{\circ} \mathrm{C}$ for $<5^{\circ} \mathrm{C}$, dried seeds moisture was measured by Grain Moisture Tester Soybeans (Baton cooperation. Model: 8500, Michigan 48084) and ground by Retsch SK 100 (Retsch GmbH, Model: SK 1001C, 42781, Haan, Germany) to produce bean seed flour. About 5-10 g of flour were scanned using X-ray Fluorescence (XRF) (Bruker AXS GmbH, Model: Tracer 5i, Östliche Rheinbrückenstr, 76187 Karlsruhe Germany) and read as $\mathrm{Fe}$ and $\mathrm{Zn}$ concentration $\mathrm{mg} / \mathrm{kg}$ for each genotype from two different environments. 


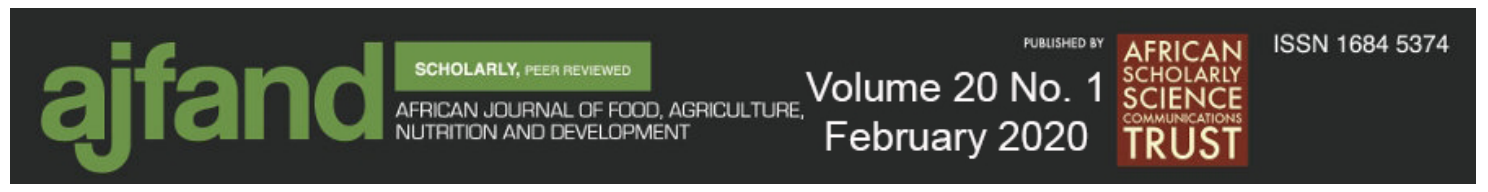

Sampling and sample preparation for cooking time determination: Harvested seeds from similar plots were sun-dried and mixed in a paper bag sized $6.5 \mathrm{~cm} \times 14 \mathrm{~cm}$ and stored at room temperature. When seed moisture reached 10-14\%, 30 seeds from each genotype were selected and measured $(\mathrm{g})$ using electronic scale by $\left(\mathrm{SONASH}{ }^{\circledR}\right.$, Model: SKS-006, Frances) after that these seeds were soaked in $150 \mathrm{ml}$ of water in a plastic jar overnight; before they were soaked, the seeds were weighed again to quantify water uptake (ml). Afterwards, 25 seeds were placed on top of each well of Matson Cooker (Customized Machining and Hydraulics Co., Winnipeg, Canada) which consisted of a plate with 25 wells for individual seeds and 25 metal pins [18]. Cooking time in minutes was recorded from 1 to 20 pins drop; that is, the time it took for $80 \%$ of the seeds to be completely pierced with an $85 \mathrm{~g}$ stainless steel rod with a $2 \mathrm{~mm}$ pin [19], after which average minutes were determined per cultivar. Proportional (\%) of water uptake was determined by using below fequation;

water uptake $(\%)=\frac{\text { seed weight after soaking }(\mathrm{g})-\text { seed weight before soaking }(\mathrm{g})}{\text { seed weight after soaking }(\mathrm{g})} \times 100$

\section{Data analysis}

The Analysis of Variance (ANOVA) from the factors were used to determine the significant effects $(p<0.05)$ among the tested environments, while Fisher's protected least significant differences (LSD) was used to identify the populations whose means differed statistically [20]. A built-in formula in excel analysis software and Pearson correlation was used for plotting graph, correlation, regression, scatter plots and pie charts.

\section{RESULTS AND DISCUSSION}

\section{Dry bean market classes}

Nine different market classes (Fig. 1) were used in this study for the wider chance to cover demand needs for specific regions, even though every region has its specific market class for dry bean cultivars. For instance, farmers in East African countries prefer red mottled, yellow and kablanket. In the USA, consumers prefer mostly pinto and navy beans, while preference in Ethiopia is navy/white beans. In this study, $77.00 \%$ of the collection was composed of three market classes, navy/white beans $(34.50 \%)$, red mottled $(32.00 \%)$, and small red $(10.50 \%)$.

\section{Iron and Zinc concentration levels of dry bean seeds}

The variation of $\mathrm{Fe}$ and $\mathrm{Zn}$ concentration levels was significantly different $(\mathrm{p}<0.001)$ for genotype by environmental interactions. Under combined analysis, SWP 09 (large and white kidney type) and ZABR 16575-24F22 (navy/white small seeded type) at Lyamungo showed a higher concentration of Fe with $128.00 \mathrm{mg} / \mathrm{kg}$ and $109.00 \mathrm{mg} / \mathrm{kg}$, respectively. At SARI, IBC 2 (navy/white and small-seeded) showed higher concentration with $113.50 \mathrm{mg} / \mathrm{kg}$, while the lower concentration of Fe observed in this cultivar at a different location may be attributed to environmental effect as the variation stated for locations at the methodology part. Results revealed that more cultivars had higher concentration levels at Lyamungo site compared to the SARI site. The majority 


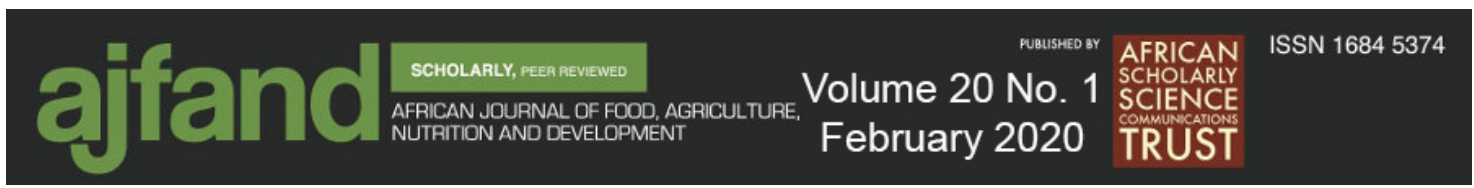

of cultivars had the concentration level of $70-80 \mathrm{mg} / \mathrm{kg}$ within the range from the minimum concentration of $46.76 \mathrm{mg} / \mathrm{kg}$ to the maximum $107.25 \mathrm{mg} / \mathrm{kg}$ based on the combined data. Apart from this, about 96 cultivars showed their concentrations above the grand mean of $77.68 \mathrm{mg} / \mathrm{kg}$ Fig. 2 (I) and Table 1. For Zn concentration in dry bean, narrow variation among the cultivars was observed by a combined analysis that showed the maximum concentration $42.35 \mathrm{mg} / \mathrm{kg}$ and the minimum $21.70 \mathrm{mg} / \mathrm{kg}$ with the grand mean $31.19 \mathrm{mg} / \mathrm{kg}$. The concentration level of $\mathrm{Zn}$ was higher at SARI with value $>42.00$ $\mathrm{mg} / \mathrm{kg}$ to some cultivars while at Lyamungo no cultivar reached this concentration Fig. 2 (II). The Fe and $\mathrm{Zn}$ concentration levels in seeds showed a positive correlation of 0.51 which means that Fe level is increasing at the same time $\mathrm{Zn}$ level increases.
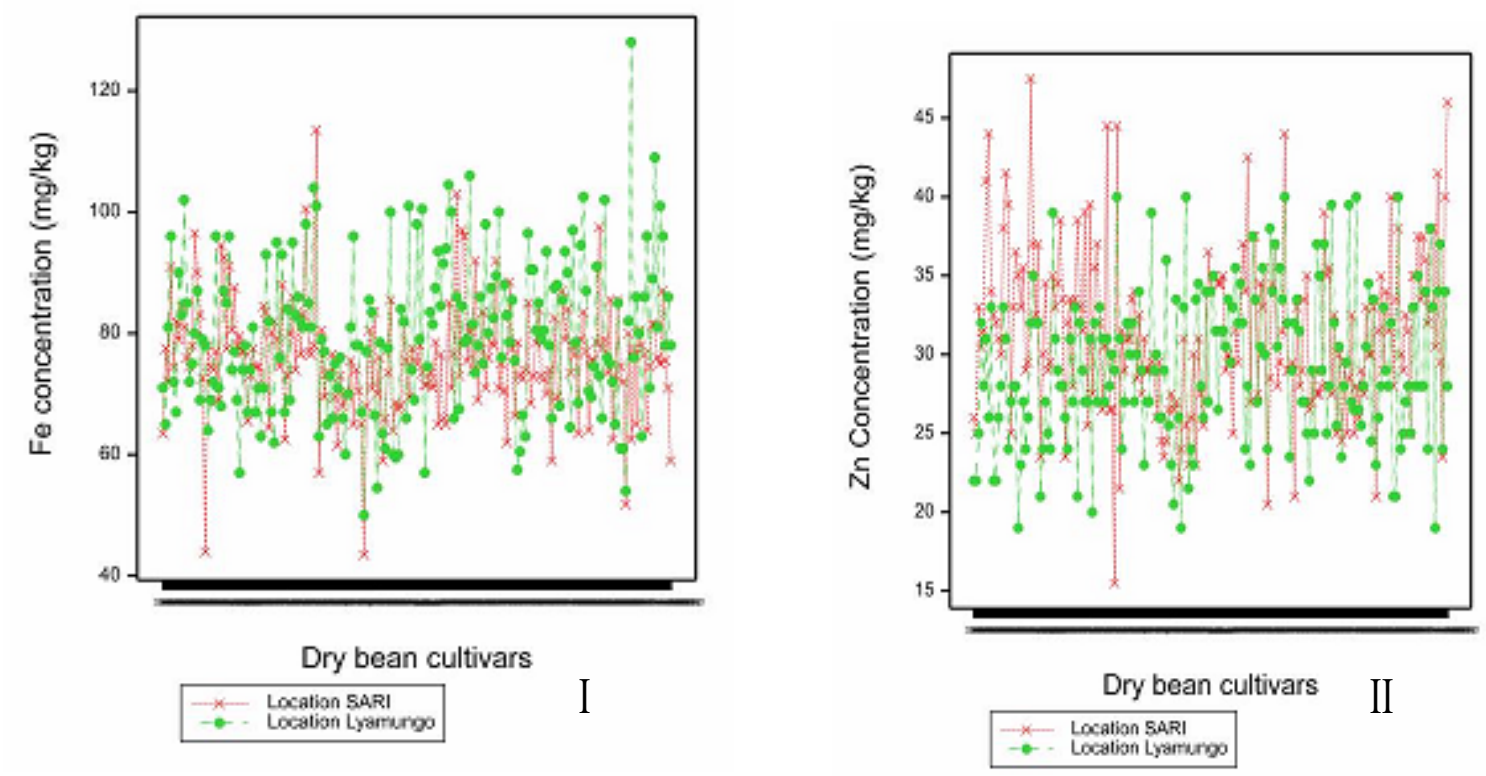

Figure 2: Iron concentration levels for genotype and environmental interactions (I), Zinc concentration levels for interaction of genotype and environment (II)

\section{Water uptake and cooking time}

Since the initial level of moisture across the samples ranged from $10-14 \%$, then from the results it showed that the maximum water uptake was $61.54 \%$ for $\mathrm{G} 79$ cultivar which is small white market class with sun-dry moisture level of $12.20 \%$. The minimum water uptake was $3.7 \%$ for MAZ 37 with sun-dry moisture level of $12.45 \%$ which belongs to the large red kidney market class. About 83 cultivars imbibed more water at the proportion of $45 \%$ to $58 \%$ Fig. 3 (I). This reflected less cooking time compared to commonly grown cultivars Lyamungo 90 and Jesca in Tanzania, which showed water uptake of between 48 and 50\%, and cooking time between 35 and $41 \mathrm{~min}$, respectively. The higher the water uptake, the shorter the cooking time it takes among the cultivars tested. Generally, small seed-sized cultivars needed less cooking time due to more water imbibed than large-seeded cultivars. For instance, Awash-1 with 53\% water uptake took 14.17 min cooking time, KG 24-43 with $47 \%$ water uptake took 18.47 min and Mexican 142 with $50 \%$ water uptake took $20.90 \mathrm{~min}$. Cooking time ranged from $14 \mathrm{~min}$ to $75 \mathrm{~min}$. About 60 cultivars from this collection took $<30$ min to cook and most of them were those with small seed size and with higher water uptake. About 73 cultivars ranged from 


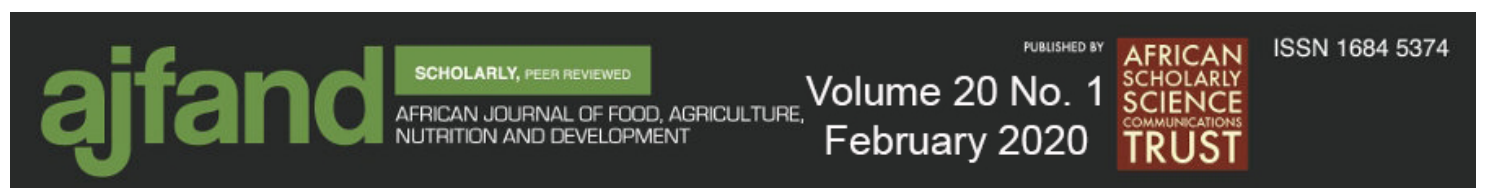

31 to 50 min for cooking time Fig. 3 (II). The analysis showed a negative correlation ( $\mathrm{r}=-$ $0.20)$ between cooking time and water uptake $(\mathrm{p}=0.01)$.
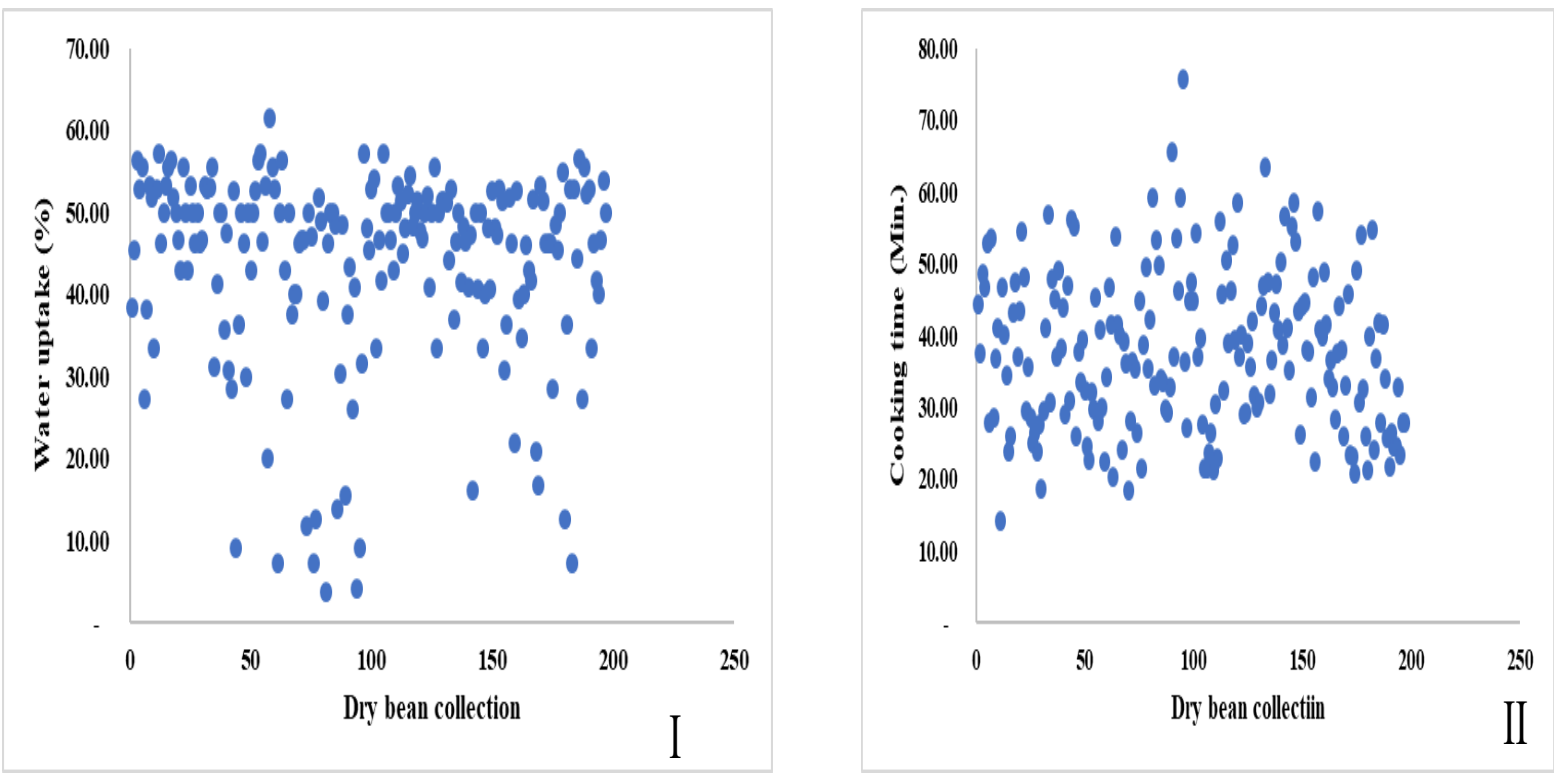

Figure 3: Illustration of Water uptake proportion (I) and Cooking time (II)

Nutrition and food systems are significant terms that are used by agricultural scientists, especially when they are conducting research for development in any field of preference. The 17 Sustainable Development Goals (SDGs) also emphasize food and nutrition through its $2^{\text {nd }}$ and $3^{\text {rd }}$ goals for zero hunger, good health and wellbeing, respectively for people [21]. Among the legumes that contribute to human nutrition, dry beans have been bred for $\mathrm{Fe}$ and $\mathrm{Zn}$ micronutrient contents. This study was to ascertain the Iron and Zinc contents of 200 cultivars collected from different places to ascertain whether they could contribute to the SDGs. This gave a wider opportunity of identifying specific market classes for specific bean growing region for improved livelihoods among the communities. This study is supported by that of Cichy et al [22] with a wider phenotypic diversity of different 206 accessions and that of Mahajan et al [23], which were looked for linkage disequilibrium based association mapping of micronutrients in different market seed classes of dry beans. In this research study, we identified some of the bean cultivars containing higher $\mathrm{Fe}$ and $\mathrm{Zn}$ concentrations from seeds although there were variations in different environments. These data are supported by other similar research conducted in Uganda [24] that showed seed concentration of up to $88 \mathrm{mg} / \mathrm{kg}$ and $41 \mathrm{mg} / \mathrm{kg}$ for Fe and $\mathrm{Zn}$, respectively. Also, in Tanzania, biofortified climbing beans with $80.30 \mathrm{mg} / \mathrm{kg}$ Fe [25], India [23], Rwanda and Democratic Republic of Congo with 94 $\mathrm{mg} / \mathrm{kg} \mathrm{Fe} \mathrm{[26]} \mathrm{were} \mathrm{discovered} \mathrm{and} \mathrm{now} \mathrm{are} \mathrm{being} \mathrm{used} \mathrm{by} \mathrm{end} \mathrm{users.} \mathrm{Based} \mathrm{on} \mathrm{these}$ results, there is a positive correlation between $\mathrm{Fe}$ and $\mathrm{Zn}$ concentrations in seeds, which implied that genetic factors for high Fe concentration are co-segregated with genetic factors for high $\mathrm{Zn}$ concentration. It could lead to a good strategy to select higher concentrations of both $\mathrm{Fe}$ and $\mathrm{Zn}$ in the dry bean breeding programs. It has also been proven that selecting for a higher Fe level in bean seeds also tends to select for increased $\mathrm{Zn}$ levels in crop seeds [27, 28]. The identified cultivars with high $\mathrm{Fe}$ and $\mathrm{Zn}$ can be used 


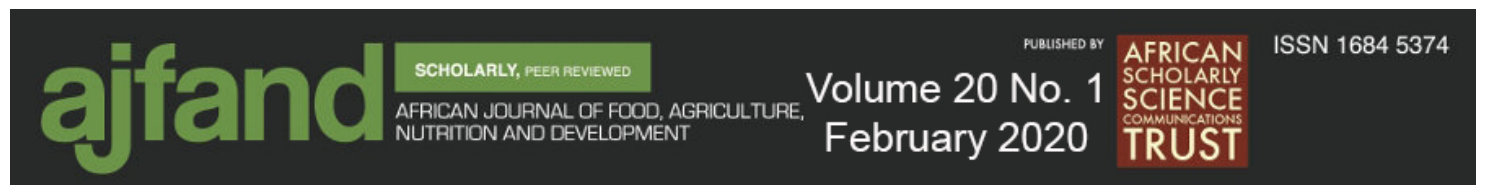

as parents in the breeding program for increasing $\mathrm{Fe}$ and $\mathrm{Zn}$ levels in specific market classes through either classical breeding or genetic engineering technologies.

In the same market class, some cultivars could be cooked in a shorter time than others. In this study, the shortest cooking time was $\sim 15$ min while the longest was $\sim 76 \mathrm{~min}$. This suggested that, in this pool of germplasm, there are cultivars of fast cooking that can be used to improve those hard cooking cultivars though their physiological and genetic mechanisms are needed to be explored. Furthermore, some cultivars were identified as possessing both desirable traits, short cooking time and higher micronutrient levels, in this study. For instance, Ranjonomby took $\sim 24$ minutes and had $90.50 \mathrm{mg} / \mathrm{kg}$ of Fe and $31.65 \mathrm{mg} / \mathrm{kg}$ of Zinc, while DOR 711 took $\sim 56$ minutes and had $73.25 \mathrm{mg} / \mathrm{kg}$ of Fe and $27.53 \mathrm{mg} / \mathrm{kg}$ of $\mathrm{Zn}$ (Table 1). This result was also supported by some studies that proved that the fast cooking seeds contained $20 \%$ more protein, $10 \%$ more iron and $10 \%$ more zinc than those that took twice as long to prepare [30] and the same study demonstrated that the iron bioavailability was higher in the quicker cooking cultivars. Seeds having a longer cooking time might cause the loss of their nutritional values during overtime cooking. A study conducted by Cichy et al.[22] analyzed the nutritional value of twelve dry bean cultivars with fast, moderate, and slow cooking time selected from four classes of yellow, cranberry, light red kidney and red mottled. Other researchers explained that the fast cooking bean cultivars maintain nutrients including protein and mineral contents after they are prepared than the moderate and slow cooking cultivars [16].

\section{CONCLUSION}

The selection of high Fe content in dry bean breeding could indirectly select high $\mathrm{Zn}$ concentration due to their positive correlation. Small seeds quickly imbibe water and lead to a short cooking time compared to large seeds. Cultivars possessing both high micronutrient levels and short cooking time were screened out by farmers. The resulting information in this study provides the benefit to consumers and dry bean breeding program for a better source of materials. These cultivars can be used as parents for $\mathrm{Fe}$ and $\mathrm{Zn}$ sources to improve micronutrient levels in the breeding program. From this study, the future research suggested will be to consider Fe bioavailability and protein contents for the few identified cultivars with enhanced $\mathrm{Fe}$ and $\mathrm{Zn}$ concentrations and fast cooking time.

\section{ACKNOWLEDGEMENTS}

This work was supported by Tuskegee University through the Integrative Biosciences (IBS) PhD Program under the synergism of the College of Agriculture, Environment and Nutrition Sciences (CAENS), College of Arts and Sciences (CAS) and College of Veterinary Medicine (CVM). Also, the Government of Tanzania (GoT) through Tanzania Agricultural Research Institute - Selian Centre and the International Center for Tropical Agriculture (CIAT) together with Pan-Africa Bean Research Alliance (PABRA). 


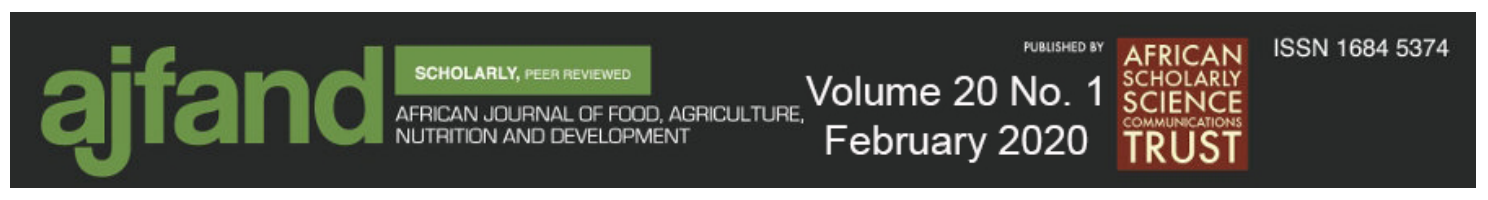

Table 1: Combined data for $\mathrm{Fe}$ and $\mathrm{Zn}$ grain concentration, water uptake and cooking time

\begin{tabular}{|c|c|c|c|c|c|}
\hline $\mathbf{S} / \mathbf{N}$ & Cultivar & $\mathrm{Fe}(\mathrm{mg} / \mathrm{kg})$ & $\mathrm{Zn}(\mathrm{mg} / \mathbf{k g})$ & W/uptake (\%) & C/time (min) \\
\hline 1 & $217 / 2$ & 67.25 & 24.11 & 38.46 & 44.26 \\
\hline 2 & $222 / 1$ & 71.25 & 23.56 & 56.25 & 48.63 \\
\hline 3 & $296 / 6$ & 76.50 & 29.44 & 52.94 & 46.70 \\
\hline 4 & A 686 & 93.50 & 31.33 & 55.56 & 52.90 \\
\hline 5 & A 774 & 73.25 & 29.83 & 27.27 & 27.86 \\
\hline 6 & A 797 & 74.50 & 36.58 & 38.10 & 53.55 \\
\hline 7 & ALS 3 & 84.50 & 37.07 & 53.33 & 28.52 \\
\hline 8 & AMENDON & 83.75 & 33.53 & 51.85 & 36.84 \\
\hline 9 & Awash Meka & 91.50 & 28.09 & 33.33 & 41.03 \\
\hline 10 & Awash-1 & 80.50 & 27.76 & 52.94 & 14.17 \\
\hline 11 & BAT 332 & 73.25 & 28.66 & 57.14 & 46.82 \\
\hline 12 & C. $2014 / \mathrm{Hu} / 11$ & 76.50 & 29.04 & 46.15 & 40.03 \\
\hline 13 & C. $2018 / \mathrm{Hu} / 11$ & 88.25 & 35.64 & 50.00 & 34.48 \\
\hline 14 & C. $2019 / \mathrm{Hu} / 11$ & 88.50 & 36.89 & 53.33 & 23.70 \\
\hline 15 & C. $202 / \mathrm{Hu} / 3$ & 76.00 & 33.41 & 56.25 & 43.21 \\
\hline 16 & CAL 113 & 75.75 & 26.12 & 51.72 & 47.42 \\
\hline 17 & CANPSULA & 61.00 & 30.65 & 50.00 & 37.00 \\
\hline 18 & CC 13 & 71.00 & 32.70 & 46.67 & 43.28 \\
\hline 19 & CC 547 & 71.75 & 29.08 & 42.86 & 54.47 \\
\hline 20 & CC 814 & 73.00 & 28.73 & 55.56 & 48.12 \\
\hline 21 & CC 906 & 86.50 & 31.72 & 50.00 & 29.40 \\
\hline 22 & CIM 9313-1 & 70.00 & 26.67 & 42.86 & 35.57 \\
\hline 23 & CN Bunsi (60) & 81.25 & 27.83 & 53.33 & 28.42 \\
\hline 24 & CN Bunsi (62) & 89.75 & 41.08 & 50.00 & 25.10 \\
\hline 25 & CN Bunsi (63) & 81.25 & 36.04 & 46.15 & 26.30 \\
\hline 26 & CN Bunsi (64) & 93.50 & 32.28 & 50.00 & 23.89 \\
\hline 27 & CN Bunsi (66) & 82.25 & 22.30 & 46.67 & 18.58 \\
\hline 28 & CN Bunsi (68) & 73.50 & 27.25 & 53.33 & 29.39 \\
\hline 29 & CORNELL 49822 & 68.25 & 31.11 & 52.94 & 41.11 \\
\hline 30 & CZ 102-24 & 75.50 & 27.10 & 53.13 & 56.94 \\
\hline 31 & CZ 108-27 & 77.50 & 26.96 & 55.56 & 30.66 \\
\hline 32 & CZ 114-46 & 66.25 & 37.21 & 31.25 & 47.83 \\
\hline 33 & CZ 114-50 & 73.50 & 32.04 & 41.18 & 45.07 \\
\hline 34 & CZ 114-51 & 79.25 & 31.93 & 50.00 & 37.13 \\
\hline 35 & CZ 114-8 & 70.75 & 33.94 & 50.00 & 49.11 \\
\hline 36 & DONTIMOTEO & 72.75 & 30.94 & 47.37 & 43.76 \\
\hline 37 & DOR 662 & 67.25 & 24.91 & 30.77 & 28.96 \\
\hline 38 & DOR 708 & 77.75 & 28.45 & 28.57 & 46.88 \\
\hline
\end{tabular}




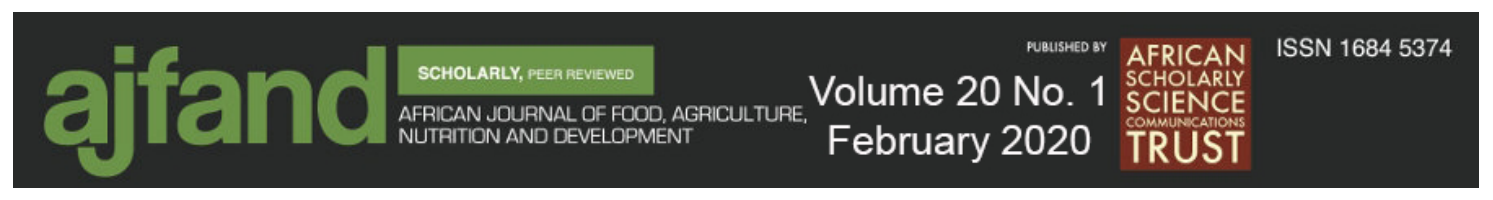

\begin{tabular}{|c|c|c|c|c|c|}
\hline 39 & DOR 710 & 88.25 & 32.29 & 52.63 & 30.98 \\
\hline 40 & DOR 711 & 73.25 & 27.53 & 9.09 & 56.18 \\
\hline 41 & DOR 755 & 73.50 & 33.28 & 36.36 & 55.20 \\
\hline 42 & DOR 766 & 72.00 & 32.03 & 35.71 & 38.16 \\
\hline 43 & F1POPULATION & 87.00 & 32.53 & 50.00 & 25.85 \\
\hline 44 & FEB 181 & 75.25 & 30.30 & 46.15 & 37.65 \\
\hline 45 & FEB 189 & 90.50 & 33.93 & 30.00 & 33.45 \\
\hline 46 & FLO DE MAYO & 64.75 & 26.34 & 50.00 & 39.47 \\
\hline 47 & G 100 & 78.50 & 35.67 & 42.86 & 32.20 \\
\hline 48 & G 23 & 74.50 & 24.20 & 50.00 & 24.49 \\
\hline 49 & G 30 & 90.50 & 33.82 & 52.63 & 22.56 \\
\hline 50 & G 31 & 78.50 & 32.65 & 56.25 & 31.99 \\
\hline 51 & G 5 & 84.75 & 32.56 & 57.14 & 29.82 \\
\hline 52 & G 5686 & 79.25 & 29.05 & 46.43 & 45.34 \\
\hline 53 & G 60 & 82.00 & 28.83 & 53.33 & 28.13 \\
\hline 54 & G 78 & 99.25 & 38.80 & 20.00 & 40.84 \\
\hline 55 & G 79 & 81.00 & 27.34 & 61.54 & 29.84 \\
\hline 56 & G 87 & 78.75 & 28.47 & 55.56 & 22.43 \\
\hline 57 & G 90 & 91.00 & 24.68 & 52.94 & 34.11 \\
\hline 58 & IBC 2 & 107.25 & 42.35 & 7.14 & 46.61 \\
\hline 59 & JESCA & 60.00 & 27.35 & 50.00 & 41.52 \\
\hline 60 & KABALABALA & 79.75 & 28.14 & 56.25 & 20.20 \\
\hline 61 & KG 114-177 & 73.25 & 28.04 & 42.86 & 53.83 \\
\hline 62 & KG 114-178 & 69.25 & 31.57 & 27.27 & 41.62 \\
\hline 63 & KG 114-179 & 73.25 & 30.53 & 50.00 & 40.17 \\
\hline 64 & KG 114-182 & 71.25 & 32.78 & 37.50 & 24.00 \\
\hline 65 & KG 114-185 & 72.25 & 30.81 & 40.00 & 39.25 \\
\hline 66 & KG 15-6 & 66.25 & 29.34 & 40.00 & 36.19 \\
\hline 67 & KG 24-43 & 74.50 & 33.33 & 46.15 & 18.47 \\
\hline 68 & KG 30-29 & 67.00 & 28.34 & 46.67 & 28.02 \\
\hline 69 & KG 4-20 & 65.25 & 27.47 & 46.67 & 36.26 \\
\hline 70 & KG 4-3 & 69.75 & 28.04 & 11.76 & 35.44 \\
\hline 71 & KG 67-10 & 78.25 & 28.04 & 50.00 & 26.31 \\
\hline 72 & KG 67-11 & 80.50 & 35.10 & 47.06 & 44.85 \\
\hline 73 & KG 67-5 & 76.00 & 29.53 & 7.14 & 21.53 \\
\hline 74 & KG 71-4 & 74.75 & 28.00 & 28.57 & 56.25 \\
\hline 75 & KG 75-5 & 74.25 & 28.26 & 12.50 & 38.67 \\
\hline 76 & KG 97-11 & 66.00 & 27.83 & 51.72 & 49.48 \\
\hline 77 & LYAMUNGO 90 & 46.76 & 25.35 & 48.84 & 35.43 \\
\hline 78 & MAZ 37 & 72.50 & 26.70 & 3.70 & 59.25 \\
\hline 79 & MAZ 41 & 83.00 & 31.60 & 46.15 & 33.10 \\
\hline
\end{tabular}




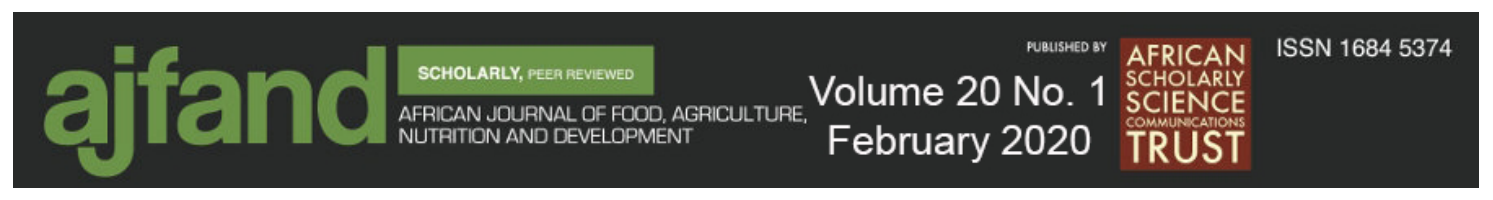

\begin{tabular}{|c|c|c|c|c|c|}
\hline 80 & MAZ 42 & 77.25 & 26.03 & 50.00 & 53.23 \\
\hline 81 & MAZ 44 & 75.00 & 25.39 & 50.00 & 49.72 \\
\hline 82 & MAZ 46 & 62.25 & 23.78 & 48.57 & 34.05 \\
\hline 83 & MAZ 47 & 77.25 & 30.76 & 13.79 & 33.49 \\
\hline 84 & MAZ 48 & 61.25 & 24.30 & 30.23 & 29.80 \\
\hline 85 & MAZ 49 & 63.50 & 21.70 & 48.48 & 29.31 \\
\hline 86 & MAZ 50 & 75.50 & 32.11 & 15.38 & 32.85 \\
\hline 87 & MAZ 52 & 92.75 & 34.64 & 37.50 & 65.62 \\
\hline 88 & MAZ 56 & 62.00 & 22.28 & 43.33 & 36.93 \\
\hline 89 & MAZ 57 & 64.00 & 25.03 & 26.09 & 53.50 \\
\hline 90 & MAZ 59 & 69.00 & 29.00 & 23.53 & 53.00 \\
\hline 91 & MAZ 70 & 63.75 & 26.85 & 40.91 & 46.17 \\
\hline 92 & MAZ 72 & 76.00 & 29.47 & 4.00 & 59.13 \\
\hline 93 & MAZ 74 & 82.00 & 32.94 & 9.09 & 75.75 \\
\hline 94 & MEX 54 & 70.75 & 27.80 & 31.58 & 36.34 \\
\hline 95 & MEXICAN 142 & 90.00 & 39.00 & 50.00 & 20.90 \\
\hline 96 & MICHETTE & 85.25 & 25.80 & 57.14 & 27.16 \\
\hline 97 & MLB 17-89A & 75.75 & 31.07 & 48.15 & 44.75 \\
\hline 98 & MLB 40-89A & 72.25 & 32.33 & 45.45 & 47.39 \\
\hline 99 & MLB 48-89A & 86.50 & 34.04 & 52.94 & 44.71 \\
\hline 100 & MONT-CALM & 78.50 & 35.04 & 54.05 & 54.26 \\
\hline 101 & Navy line 15 & 87.00 & 33.32 & 46.67 & 39.62 \\
\hline 102 & Navy line 19 & 64.25 & 30.92 & 41.67 & 27.63 \\
\hline 103 & Navy line 22 & 97.00 & 31.50 & 45.45 & 52.02 \\
\hline 104 & Navy line 25 & 73.00 & 33.06 & 57.14 & 21.50 \\
\hline 105 & Navy line 38 & 78.50 & 33.32 & 50.00 & 21.49 \\
\hline 106 & Navy line 40 & 76.30 & 29.84 & 33.33 & 37.03 \\
\hline 107 & Navy line 43 & 83.00 & 31.95 & 50.00 & 23.62 \\
\hline 108 & Navy line 48 & 79.25 & 29.54 & 46.67 & 26.44 \\
\hline 109 & Navy line 5 & 65.50 & 27.00 & 55.00 & 24.37 \\
\hline 110 & Navy line 51 & 80.50 & 29.75 & 42.86 & 21.16 \\
\hline 111 & Navy line 52 & 78.75 & 33.73 & 50.00 & 30.30 \\
\hline 112 & Navy line 54 & 79.50 & 30.89 & 53.33 & 22.79 \\
\hline 113 & NUA 11 & 94.75 & 33.38 & 51.43 & 55.95 \\
\hline 114 & NUA 110 & 85.50 & 34.64 & 44.90 & 45.70 \\
\hline 115 & NUA 116 & 71.25 & 29.71 & 52.17 & 50.55 \\
\hline 116 & NUA 117 & 94.50 & 36.55 & 54.55 & 39.00 \\
\hline 117 & NUA 125 & 70.25 & 25.11 & 48.39 & 46.25 \\
\hline 118 & NUA 129 & 90.75 & 37.54 & 50.00 & 52.51 \\
\hline 119 & NUA 13 & 83.50 & 35.00 & 52.63 & 38.75 \\
\hline 120 & NUA 130 & 87.25 & 35.59 & 51.43 & 39.30 \\
\hline
\end{tabular}




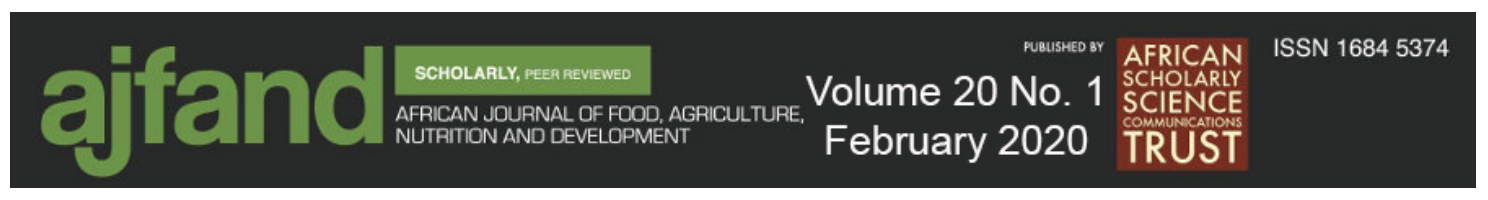

\begin{tabular}{|c|c|}
\hline 121 & NUA 134 \\
\hline 122 & NUA 137 \\
\hline 123 & NUA 145 \\
\hline & NUA 15 \\
\hline 125 & NUA 152 \\
\hline 126 & NUA 156 \\
\hline 127 & NUA 158 \\
\hline 128 & NUA 16 \\
\hline 129 & NUA 160 \\
\hline 130 & NUA 161 \\
\hline 131 & NUA 163 \\
\hline 132 & NUA 165 \\
\hline 133 & NUA 17 \\
\hline 134 & NUA 18 \\
\hline 135 & NUA 19 \\
\hline 136 & NUA 200 \\
\hline 137 & NUA 204 \\
\hline 138 & NUA 207 \\
\hline 139 & NUA 209 \\
\hline 140 & NUA 210 \\
\hline 141 & NUA 211 \\
\hline 142 & NUA 212 \\
\hline 143 & NUA 213 \\
\hline 144 & NUA 224 \\
\hline 145 & NUA 225 \\
\hline 146 & NUA 226 \\
\hline 147 & NUA 229 \\
\hline 148 & NUA 23 \\
\hline 149 & NUA 231 \\
\hline 150 & NUA 232 \\
\hline 151 & NUA 233 \\
\hline 152 & NUA 235 \\
\hline 153 & NUA 236 \\
\hline 154 & NUA 238 \\
\hline 155 & NUA 240 \\
\hline 156 & NUA 244 \\
\hline 157 & NUA 245 \\
\hline 158 & NUA 256 \\
\hline 159 & NUA 257 \\
\hline 160 & NUA 272 \\
\hline 161 & NUA 273 \\
\hline
\end{tabular}

$\begin{array}{ll}77.25 & 27.28 \\ 93.25 & 32.59 \\ 77.75 & 34.38 \\ 82.75 & 32.93 \\ 73.50 & 22.52 \\ 81.75 & 34.13 \\ 79.25 & 34.28 \\ 84.50 & 37.04 \\ 78.00 & 29.39 \\ 83.00 & 32.92 \\ 80.25 & 32.61 \\ 90.75 & 42.08 \\ 85.50 & 30.67 \\ 75.50 & 26.46 \\ 79.25 & 29.28 \\ 72.50 & 27.91 \\ 83.50 & 33.30 \\ 81.50 & 29.96 \\ 71.00 & 28.04 \\ 68.00 & 30.52 \\ 66.75 & 30.69 \\ 69.50 & 24.39 \\ 68.50 & 28.12 \\ 90.75 & 27.10 \\ 79.50 & 33.15 \\ 81.75 & 31.87 \\ 88.50 & 29.50 \\ 79.50 & 28.57 \\ 84.50 & 38.04 \\ 76.00 & 30.69 \\ 76.50 & 32.10 \\ 81.75 & 34.82 \\ 76.00 & 32.28 \\ 62.50 & 25.30 \\ 78.75 & 24.03 \\ 68.25 & 28.78 \\ 86.25 & 27.57 \\ 86.25 & 35.11 \\ 87.00 & 29.94 \\ 65.50 & 34.00 \\ 69.00 & 25.84\end{array}$

$\begin{array}{ll}47.62 & 58.60 \\ 46.88 & 37.05 \\ 50.00 & 40.10 \\ 52.00 & 28.94 \\ 40.91 & 29.25 \\ 50.00 & 38.90 \\ 55.56 & 35.70 \\ 33.33 & 42.05 \\ 50.00 & 31.65 \\ 51.35 & 30.00 \\ 51.35 & 30.60 \\ 51.22 & 44.10 \\ 44.12 & 46.95 \\ 52.94 & 63.54 \\ 37.04 & 47.40 \\ 46.43 & 31.94 \\ 50.00 & 36.45 \\ 41.46 & 43.15 \\ 48.39 & 47.20 \\ 46.43 & 40.85 \\ 40.91 & 50.30 \\ 47.22 & 38.60 \\ 16.00 & 56.70 \\ 50.00 & 41.10 \\ 40.74 & 35.05 \\ 50.00 & 55.10 \\ 46.43 & 38.80 \\ 33.33 & 58.60 \\ 40.00 & 53.00 \\ 48.15 & 43.35 \\ 40.74 & 26.20 \\ 52.63 & 44.00 \\ 48.15 & 44.60 \\ 47.17 & 38.05 \\ 51.35 & 31.45 \\ 30.77 & 48.15 \\ 36.36 & 22.45 \\ 51.72 & 57.40 \\ 46.15 & 40.75 \\ 52.63 & 42.65 \\ 21.95 & 39.90\end{array}$




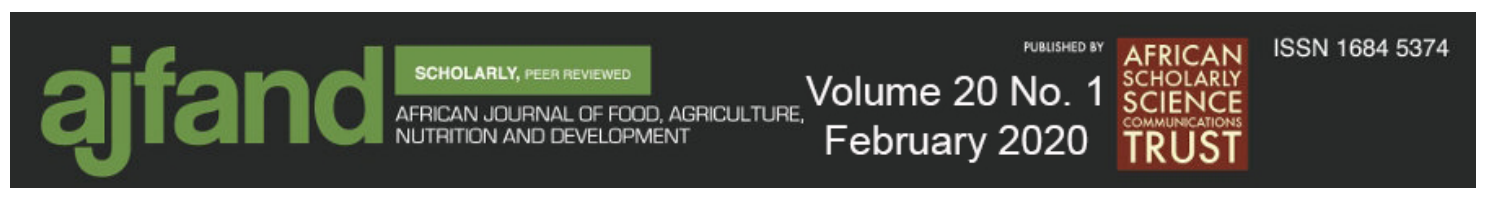

\begin{tabular}{|c|c|c|c|c|c|}
\hline 162 & NUA 30 & 87.50 & 35.30 & 52.63 & 48.74 \\
\hline 163 & NUA 31 & 77.50 & 26.30 & 39.39 & 41.60 \\
\hline 164 & NUA 39 & 66.00 & 27.33 & 34.62 & 33.85 \\
\hline 165 & NUA 40 & 86.75 & 27.80 & 40.00 & 36.55 \\
\hline 166 & NUA 48 & 93.00 & 31.79 & 45.95 & 32.75 \\
\hline 167 & NUA 57 & 82.00 & 32.53 & 42.86 & 28.25 \\
\hline 168 & NUA 64 & 67.25 & 27.45 & 41.67 & 37.40 \\
\hline 169 & NUA 66 & 112.00 & 37.00 & 51.52 & 39.66 \\
\hline 170 & NUA 67 & 72.50 & 33.30 & 51.61 & 44.20 \\
\hline 171 & NUA 9 & 75.00 & 22.14 & 20.83 & 37.95 \\
\hline 172 & PAN 72 & 84.75 & 28.95 & 16.67 & 26.00 \\
\hline 173 & PI 207262 & 85.25 & 31.80 & 53.33 & 32.98 \\
\hline 174 & R.K. MICHIGA & 71.75 & 31.24 & 51.35 & 45.82 \\
\hline 175 & RANJONOMBY & 90.50 & 31.65 & 46.15 & 23.42 \\
\hline 176 & RAZ 36 & 74.75 & 29.83 & 46.15 & 23.19 \\
\hline 177 & RAZ 44 & 80.25 & 36.36 & 46.15 & 20.69 \\
\hline 178 & RRN 47 & 67.25 & 24.88 & 28.57 & 49.03 \\
\hline 179 & RRN 48 & 69.00 & 28.47 & 48.48 & 30.76 \\
\hline 180 & RWR 1059 & 85.25 & 39.09 & 45.45 & 54.12 \\
\hline 181 & RWR 2075 & 67.75 & 27.25 & 50.00 & 32.52 \\
\hline 182 & SAB 662 & 66.50 & 27.10 & 55.00 & 25.97 \\
\hline 183 & SELIAN 05 & 52.90 & 29.94 & 12.50 & 21.17 \\
\hline 184 & SM 133 & 81.00 & 29.83 & 36.36 & 39.87 \\
\hline 185 & SWP 09 & 95.25 & 25.04 & 52.94 & 54.83 \\
\hline 186 & SWP 10 & 76.75 & 34.04 & 7.14 & 24.08 \\
\hline 187 & SWP 12 & 75.50 & 31.80 & 52.94 & 36.76 \\
\hline 188 & $\mathrm{TU}$ & 80.25 & 36.29 & 44.44 & 41.63 \\
\hline 189 & VAX 1 & 70.50 & 30.94 & 56.52 & 27.76 \\
\hline 190 & VAX 2 & 81.25 & 33.32 & 27.27 & 41.55 \\
\hline 191 & ZABR 16573-78F22 & 80.00 & 35.04 & 55.56 & 33.98 \\
\hline 192 & ZABR 16575-11F22 & 78.50 & 37.19 & 52.94 & 21.58 \\
\hline 193 & ZABR 16575-17F22 & 85.25 & 38.04 & 33.33 & 26.43 \\
\hline 194 & ZABR 16575-24F22 & 95.25 & 35.64 & 46.15 & 24.51 \\
\hline 195 & ZABR 16575-39F22 & 78.50 & 25.87 & 41.67 & 24.40 \\
\hline 196 & ZABR 16575-46F22 & 72.75 & 28.45 & 52.17 & 25.61 \\
\hline 197 & ZABR 16575-51F22 & 88.00 & 38.05 & 40.00 & 32.70 \\
\hline 198 & ZABR 16575-60F22 & 91.50 & 33.84 & 46.67 & 23.40 \\
\hline 199 & ZABR $16575-86 F 22$ & 76.75 & 23.80 & 53.85 & 27.75 \\
\hline \multirow[t]{3}{*}{200} & ZABR 16577-51F22 & 68.50 & 38.96 & 50.00 & 27.86 \\
\hline & Mean & 77.68 & 31.19 & 43.63 & 37.74 \\
\hline & SGE $(5 \%)$ & $<0.001$ & $<0.001$ & 0.01 & 0.01 \\
\hline
\end{tabular}




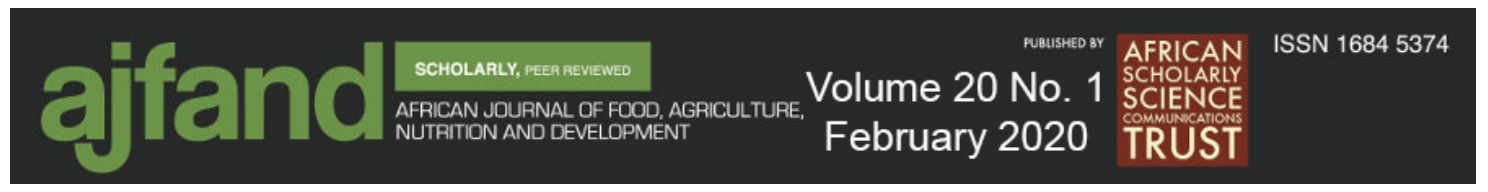

\section{REFERENCES}

1. Murarka S, Mishra V, Joshi $\mathbf{P}$ and $\mathbf{S}$ Kumar Role of Zinc in reproductive biology - An overview. Austin Journal of Reproduction Infertility. 2015; 2(2):1009-1013.

2. Tapiero $\mathbf{H}$ and $\mathbf{K}$ Tew Trace element in human physiology and pathology: Zinc and metallothioneins. Biomedical Pharmacother. 2003; 57:399-411.

3. Lin Y, Chang T, Tseng Y, Huang F and F Kung Seminal plasma zinc levels and sperm motion characteristics in infertile samples. Chang Gung Medical Journal. 2000; 23:260-266.

4. Haas $\mathbf{J}$ and $\mathbf{T}$ Brownlie Iron deficiency and reduced work capacit: A critical review of the research to determine a casual relationship. Journal of Nutrition. $2001 ; 131-138$

5. Stolzfus $\mathbf{N}$ and $\mathbf{D}$ Walkey Iron deficiency global prevalence and consequences. Food Nutrition Bulletin, 2003; 24:100-103.

6. Zimmermann M Nutrition Iron defifiency. Lancet. 2007; 370:511-520.

7. Bouis H, Hotz $\mathbf{C}$, McClaffet B, Meenakshi $\mathbf{J}$ and $\mathbf{W}$ Pfeiffer Biofortification: A new tool to reduce micronutrient malnutrition. Food Nutrition Bulletin, 2011; 3:3140 .

8. HarvestPlus. HarvestPlus 2018. [Online]. Available: www.harvestplus.org. Accessed: 2019 August 10.

9. Broughton W, Hernandez G, Blair MBS, Gepts $\mathbf{P}$ and $\mathbf{J}$ Vanderleyden Beans (Phaseolus vulgrais spp.)-model food legumes. Plants and Soils. 2003; 55-128.

10. Blair M, Gonzales $\mathbf{L}$, Kiman $\mathbf{P}$ and $\mathbf{L}$ Butare Genetic diversity, intergene pool introgression and nutritional quality of common beans (Phaseolus vulgaris L.) from central Africa. Theor. App. Gen. 2010; 121:237-248.

11 Welch R, House W, Beebe $\mathbf{S}$ and $\mathbf{Z}$ Cheng Genetic selection for enhanced bioavalible levels of Iron in beans (Phaseolus, vulgaris L.) seeds. J. of Agric. Food Chem. 2000; 48:3576-3580.

12. Menendez A and M Curt Energy and socioeconomic profile ofsmall rural community in the highlands of central Tanzania: a case study. Energy Sustainable Development, 2013; 17:201-209.

13. Felix $\mathbf{M}$ and $\mathbf{S}$ Gheewala A review of biomass energy dependency in Tanzania," Energy procedia, 2011; 9:338-343. 


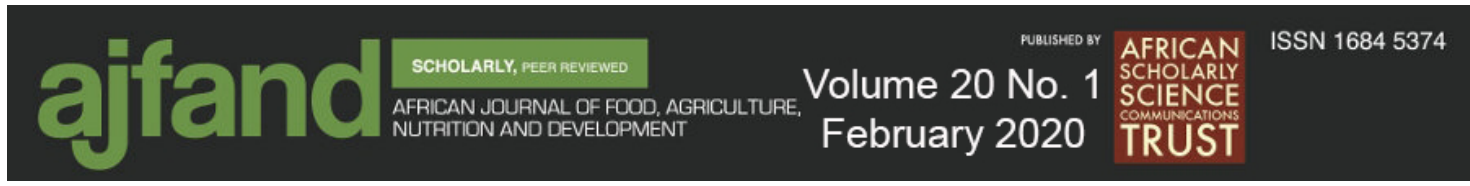

14. Brouwer I Nutritional impacts of an increasing fuelwood shoratage in rural household in developing cpuntries. Prog. Food Nutr. Sc. 1989; 13:349-361.

15. Smith $\mathbf{L}, \mathbf{N g} \mathbf{S}$ and B Popkin Trends in US home food preparation and consumption: Analysis of national surveys and time use studies from 1965-1966 to 20017-2008. Nutritional Journal. 2013; 12:45-47.

16. Wiesinger J, Cichy $\mathbf{K}$, Glahn $\mathbf{R}$, Grusak M, Brick $\mathbf{M}$, Thompson $\mathbf{H}$ and $\mathbf{E}$ Tako Demonstrating a Nutritional Advantage to the Fast-Cooking Dry Bean (Phaseolus vulgaris L.) J. Agric. and Food Chem. 2016; 8592-8603.

17. Brady $\mathbf{N}$ and $\mathbf{R}$ Weil The nature and properties of soils, Upper saddle, New Jersey: Prentice Hall, 2002.

18. Wang $\mathbf{N}$ and $\mathbf{J}$ Daun Determination of cooking times of pulses using an automated cooker apparatus. J. Sc. \& Food Agric. . 2005; 85:1631-1635.

19. Mattson S The Cookability of yellow peas. Acta Agricultural Scand. 1946; 2:189191, 1946.

20. GenStat GenStat Procedure Library. Release 16.2 (PC/Windows 10) PL24.2 VSN International Ltd Rothamted, UK, 2013.

21. UN-SDG. Transforming our world: the 2013 agenda for sustainable development. 2207 2014. [Online]. Available: www.sustainabledevelopment.un.org. Accesssed: 2019 July 23.

22. Cichy K, Porch T, Beaver J, Cregan DFD, Glahn R, Grusak M, Kamfwa K Katuuramu D, Phil P, McClean E, Mndolwa E, Nchimbi-Msolla S, PastorCorrales $\mathbf{M}$ and $\mathbf{P}$ Miklas A Phaseolus vulgaris Diversity Panel for Andean Bean Improvement. Crop Science, 2015; 55:2149-2160.

23. Mahajan R, Zargar S, Salgotra R, Singh RWA, Nazir M and P Sofi Linkage disequilibrium based association mapping of micronutrients in common bean (Phaseolus vulgaris L.): a collection of Jammu \& Kashmir, India. Biotechnology, 2017; 7:295.

24. Among A, Mukankusi C, Sebuliba S and F Mukamuhirwa Iron and zinc grain concentrations diversity and agronomic performance of common bean germplasm collected from East Africa. Afr. J. Food, Agric. Nutr. \& Devel. 2018; 18(03):13717-13742.

25. Nestory S, Mdachi M, William M, Kadege E, Kessy G, Mugunda D, Msaky M and J Rubyogo Grain Yield Performance of Biofortified Climbing Common Bean Genotypes (Phaseolus Vulgaris L.) Evaluated Across Different Agro-ecologies in Tanzania. J. of Biol., Agric. \& Healthcare, 2019; 9(4): 36-40, 2019. 


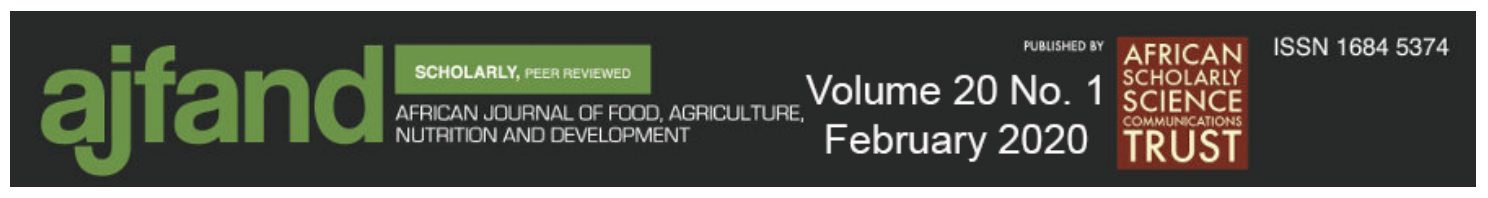

26. Blair M, Monserrate F, Beebe $\mathbf{S}$, Restrepo J and J Flores Registration of high mineral common bean germplasm lines NUA35 and NUA56 from the red-mottled seed class. Journal of Plant Registration. 2010; 4:55-59, 2010.

27. Monasterio I and R Graham Breeding for trace elements in wheat. Food Nutrition Bulletin. 2000; 21:392-396.

28. Gregorio G, Senadhira D, Htut $\mathbf{T}$ and $\mathbf{R}$ Graham Breeding for trace mineral density in rice. Food Nutrition Bulletin. 2000; 21:382-386.

29. Kiriba D, Msaky M, Mahenge N, Paul S, Kessy G and P Binagwa Yield response of bush bean varieties (Phaseollus vulgaris)to different planting densities and rates of phosphorus fertilizer. African Journal of Agricultural Research. 2020; 15(1) 40-48.

30. Wiesinger JA, Cichy KA, Glahn RP, Grusak MA, Brick MA, Thompson HJ and E Tako Demonstrating a Nutritional Advantage to the Fast cooking Dry Bean (Phaseolus vulgaris L.) J. Agric. Food Chem. 2016;64 (45):8596-8603. 